\title{
ETNOBOTANI TANAMAN ANTIPIRETIK MASYARAKAT DUSUN MESU BOTO JATIROTO WONOGIRI JAWA TENGAH
}

\section{ETHNOBOTANY ANTIPYRETIC PLANTS PEOPLES IN DUSUN MESU BOTO JATIROTO WONOGIRI CENTRAL JAVA}

\author{
Arum Suproborini ${ }^{1)}$,Mochamad Soeprijadi Djoko Laksana ${ }^{2)}$,Dwi Fitri Yudiantoro ${ }^{3)}$ \\ ${ }^{1)}$ Progam Studi Farmasi Fakultas Ilmu Kesehatan dan Sain Universitas PGRI Madiun,Indonesia \\ ${ }^{2)}$ Program Studi PGSD Fakultas Keguruan dan Ilmu Pendidikan Universitas PGRI Madiun, \\ Indonesia \\ ${ }^{3)}$ Fakultas Teknik Geologi Universitas Pembangunan Nasional Veteran Yogyakarta, Indonesia \\ arum@unipma.ac.id
}

\begin{abstract}
ABSTRAK
Pengobatan tradisional di Indonesia sudah di kenal masyarakat jauh sebelum pelayanan kesehatan formal dengan obat-obatan modern. Indonesia memiliki banyak spesies tanaman yang mempunyai khasiat untuk menyembuhkan berbagai macam penyakit dan beberapa khasiat lainnya yang berguna bagi kesehatan manusia. Tanaman antipiretik adalah tanaman yang mempunyai khasiat sebagai obat penurun panas. Kandungan flavonoid pada tanaman berhasiat sebagai pereda demam (antipiretik). Penelitian ini bertujuan untuk mengetahui tanaman pekarangan yang dapat dimanfaatkan oleh masyarakat sebagai obat penurun panas (antipiretik). Metode penelitian yang digunakan adalah metode survey. Lokasi pengamatan dan pengambilan sampel tanaman dilakukan dengan teknik purposive random sampling yaitu dengan membuat plot petak ukuran $2 \times 2$ meter, $5 \times 5$ meter (menyesuaikan lokasi lahan). Berdasarkan hasil penelitian dan pengamatan terdapat 8 spesies tanaman antipiretik yaitu kunyit (Curcuma domestica), pepaya (Carica papaya), dadap (Erythrina sp), bunga sepatu (Hibiscus rosasinensis), rambutan (Nephelium lappaceum), pisang (Musa paradisiaca), sirsak (Annona muricata), dan bengkuang (Pachirrhyzus erosus) yang dapat dimanfaatkan oleh masyarakat setempat.
\end{abstract}

Kata kunci : tanaman, antipiretik, flavonoid.

\begin{abstract}
Traditional medicine in Indonesia has been known to the public long before formal health services with modern medicine. Indonesia has many species of plants that have properties to cure various diseases and some other useful properties for human health. Antipyretic plants are plants that have the property as a febrifuge. The content of flavonoids in plants merit as a reliever fever (antipyretic). This study aims to determine the garden plants that can be utilized by the community as a febrifuge. (antipyretic). The research method used is survey method. The location of the observation and sampling of the plants was done by purposive random sampling technique by plot plot size 2x2 meter, 5x5 meter (adjust the location of the land). Based on research and observation, there are 8 species of antipyretic plants tumeric (Curcuma domestica), papaya (Carica papaya), dadap (Erythrina sp), hibiscus (Hibiscus rosasinensis), rambutan (Nephelium lappaceum), banana (Musa paradisiaca), soursop (Annona muricata), and yam (Pachirrhyzus erosus) which can be utilized by the local community.

Keywords: plant, antipyretic, flavonoid.
\end{abstract}




\section{Journal of Pharmaceutical Science and Medical Research \\ ISSN 2614-4840 (print) 2614-6118 (online)}

Vol. 1 No. 1 Tahun 2018

\section{PENDAHULUAN}

Kabupaten Wonogiri adalah salah satu kabupaten di Jawa Tengah, terdiri dari 25 kecamatan. Jatiroto adalah salah satu kecamatan di Kabupaten Wonogiri yang terdiri dari 15 Desa/Kelurahan, salah satunya adalah desa Boto. Desa Boto meliputi 5 dusun yang terdiri dari dusun Mipitan, Paro, Boto, Mesu, dan Dungkul. Penduduk dusun Mesu sebagian besar bermatapencaharian sebagai petani. Hasil pertanian utamanya adalah padi, selain itu juga jagung, ubi kayu, beberapa tanaman buah diantaranya mangga, rambutan, dan pepaya, juga terdapat tanaman perkebunan diantaranya jambu mete, kelapa, dan cengkeh. Berdasarkan hasil penelitian Suproborini, A (2017) di kawasan penambangan emas rakyat dusun Mesu terdapat 33 spesies tanaman yang tumbuh di pekarangan yang terdiri dari tanaman bunga, empon-empon, sayuran, tanaman buah, tanaman perkebunan dan beberapa tanaman penghasil kayu. Diantara spesies tanaman tersebut banyak yang dimanfaatkan oleh masyarakat sebagai obat.

Pengobatan tradisional di Indonesia sudah dikenal masyarakat jauh sebelum adanya pelayanan kesehatan formal dengan obat-obatan modern seperti sekarang ini. Indonesia memiliki sumber daya hayati khususnya flora yang berkhasiat untuk menyembuhkan berbagai macam penyakit dan berguna bagi kesehatan manusia. Tanaman yang berkhasiat obat mempunyai efek samping yang relatif lebih kecil dibandingkan dengan obat kimia (Rifatul, 2009). Pengobatan tradisional merupakan bagian dari sistem budaya masyarakat yang manfaatnya sangat besar dalam pembangunan kesehatan masyarakat. WHO mendukung gerakan untuk back to nature dengan merekomendasi penggunaan obat herbal dalam pemeliharaan kesehatan masyarakat, pencegahan dan untuk pengobatan berbagai macam penyakit, terutama untuk penyakit kronis, penyakit degeneratif dan kanker (Novri, dkk., 2011).

Etnobotani berasal dari kata "etnologi" yang berarti kajian mengenai budaya, dan "botani" yang berarti kajian mengenai tumbuhan. Etnobotani adalah suatu bidang ilmu yang mempelajari hubungan antara manusia dan tumbuhan. Etnobotani merupakan studi mengenai pengetahuan masyarakat lokal tentang botani. Ilmu etnobotani berkisar pada pemanfaatan tumbuh-tumbuhan oleh orang-orang di sekitarnya, yang pada aplikasinya mampu meningkatkan daya hidup manusia.

Demam merupakan salah satu gangguan kesehatan yang hampir pernah dirasakan oleh setiap orang. Demam ditandai dengan kenaikan suhu tubuh di atas suhu tubuh normal yaitu $36-37{ }^{\circ} \mathrm{C}$, yang diawali dengan kondisi menggigil pada saat terjadi peningkatan suhu, dan setelah itu terjadi kemerahan pada permukaan kulit. Pengaturan suhu tubuh terdapat pada bagian otak yang disebut hipotalamus.

Penyebab utama demam adalah infeksi oleh bakteri dan virus, meskipun ada beberapa jenis demam yang tidak diakibatkan oleh infeksi melainkan oleh kondisi patologis yang lain seperti serangan jantung, tumor, kerusakan jaringan yang disebabkan oleh sinar $\mathrm{X}$, efek 


\section{Journal of Pharmaceutical Science and Medical Research \\ ISSN 2614-4840 (print) 2614-6118 (online)}

Vol. 1 No. 1 Tahun 2018

pembedahan dan respons dari pemberian vaksin. Dinding sel bakteri mengandung zat yang bersifat pirogen, yaitu dapat menyebabkan peningkatan suhu. Antipiretik adalah golongan obat dengan target untuk menurunkan temperatur badan. Obat yang termasuk antipiretik diantaranya adalah acetaminophen, ibuprofen dan aspirin (Yusri, D.J. dkk., 2015). Menurut Husori, D.I., 2016) obat yang mampu menurunkan suhu demam kembali ke suhu normal bekerja melalui penghambatan enzim siklooksigenase-2 di susunan saraf pusat sehingga dapat mencegah terjadinya konversi asam arakidonat menjadi prostaglandin yang merupakan mediator demam.

Mekanisme aksi antipiretik adalah dengan memblokade produksi prostaglandin yang berperan sebagai penginduksi suhu di termostat hipotalamus.

Sediaan antipiretik sintetik yang banyak dikonsumsi untuk menurunkan demam, diantaranya adalah parasetamol (Leonis, M.A. et al., 2013), ibuprofen (Nayudi,S.H. et al., 2013) dan aspirin (Yusri, D.J. dkk., 2015) sering kali berdampak pada mual, muntah, nyeri, dan kerusakan organ, terutama hati atau hepatotoksisitas. Mengingat kerugian yang ditimbulkan oleh parasetamol, ibuprofen,dan aspirin, masyarakat mulai mengurangi penggunaan sediaan antipiretik sintetik tersebut dan mulai beralih ke tanaman yang berkhasiat antipiretik. Tanaman obat dinilai mempunyai keamanan yang relatif tinggi dengan tingkat efektivitas yang tidak kalah dengan sediaan antipiretik sintetik. Laporan penelitian (Wan.J. et al., 2011 dan Jethani. B. et al., 2011) menyatakan bahwa tanaman berkhasiat antipiretik itu pada umumnya mempunyai aktivitas yang menghambat enzim cyclooxygenase (COX). Menurut Andriana, D. (2007) bahwa flavonoid sebagai senyawa bahan alam yang dihasilkan tanaman memiliki berbagai macam bioaktivitas, diantaranya adalah efek antipiretik, analgetik dan antiinflamasi. Flavonoid bekerja sebagai inhibitor cyclooxygenase (COX). Cyclooxygenase (COX) akan menghambat pembentukan prostaglandin sehingga tidak terjadi demam. Penelitian ini bertujuan untuk mengetahui tanaman pekarangan masyarakat dusun Mesu yang berkhasiat sebagai tanaman penurun panas (antipiretik).

\section{METODE}

Penelitian ini dilakukan di kawasan penambangan emas rakyat Dusun Mesu Desa Boto Kecamatan Jatiroto Kabupaten Wonogiri. Peta lokasi daerah penelitian dapat dilihat pada Gambar 1. 


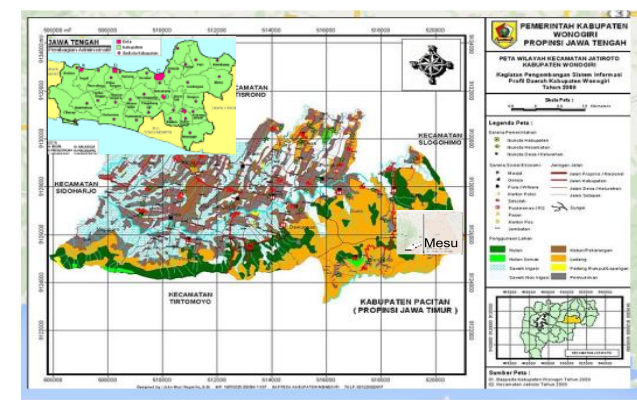

749'40,04’'S ; $110^{\circ} 58^{\prime} 33,45^{\prime \prime} \mathrm{E}$

Gambar 1. Peta lokasi daerah penelitian (Suproborini, A., 2017).

\section{Alat dan bahan}

Alat dan bahan yang digunakan adalah : buku catatan lapangan, polpen, tali rafia, pathok kayu, kamera, GPS (Global Positioning System) merk Tom Tam VIA 260.

\section{Prosedur kerja}

\section{a. Penentuan lokasi pengamatan}

Penelitian ini menggunakan metode survey. Lokasi pengamatan ditentukan dengan menggunakan teknik purposive random sampling.

b.Penentuan sampel titik hitung pengamatan

Penentuan sampel titik hitung pengamatan dibantu dengan GPS (Global Positioning System)

\section{c. Pengambilan data}

Observasi lapangan pada setiap lokasi pengamatan.

Lokasi pengamatan dan pengambilan sampel dilakukan di pekarangan pemukiman penduduk yang melakukan pengolahan emas.
Pengambilan sampel dengan menggunakan metode survey dengan teknik purposive random sampling. Metode ini dilakukan dengan membuat plot petak menggunakan rafia dengan ukuran $2 \times 2$ meter, $5 \times 5$ meter dan 10x10 meter (menyesuaikan lahan) diletakkan di sekitar tailling mengikuti aliran air pembuangan penggolahan emas, semuanya ada 19 plot sampling dengan luas total 0,1 ha. Di masingmasing plot pengamatan dicatat jenis tanaman yang berkhasiat sebagai tanaman antipiretik (penurun panas).

\section{HASIL DAN PEMBAHASAN}

Berdasarkan hasil pengamatan didapatkan 8 spesies tanaman yang berkhasiat sebagai tanaman antipiretik (Tabel 1). 


\section{Journal of Pharmaceutical Science and Medical Research \\ ISSN 2614-4840 (print) 2614-6118 (online)}

Vol. 1 No. 1 Tahun 2018

Tabel 1. Spesies tanaman yang berkhasiat sebagai antipiretik.

\begin{tabular}{lll}
\hline No. & \multicolumn{1}{c}{ Nama ilmiah } & \multicolumn{1}{c}{ Nama Lokal } \\
\hline 1. & Curcuma domestica & Kunyit \\
\hline 2. & Carica papaya & Pepaya \\
\hline 3. & Erythrina lithosperma Miq & Dadap serep \\
\hline 4. & Hibiscus rosasinensis & Kembang sepatu \\
\hline 5. & Nephelium lappaceum & Rambutan \\
\hline 6. & Musa paradisiaca & Pisang \\
\hline 7. & Annona muricata & Sirsak \\
\hline 8. & Pachirrhyzus erosus & Bengkuang \\
\hline
\end{tabular}

\section{Kunyit (Curcuma domestica)}

Pengobatan demam dapat dilakukan dengan menggunakan terapi farmakologi dan non farmakologi. Salah satu pengobatan non farmakologi yaitu dengan memanfaatkan terapi herbal sebagai antipiretik dan salah satunya yaitu dengan pemanfaatan tanaman rimpang kunyit (Kohli et al., 2005).

Rimpang kunyit merupakan salah satu tanaman herbal yang dapat digunakan sebagai obat demam. Salah satu kandungan senyawa kunyit yang diduga dapat mengobati demam adalah flavonoid. Efek antipiretik dari ekstrak rimpang kunyit ini kemungkinan disebabkan oleh kandungan fenol, salah satunya yaitu senyawa flavonoid. Senyawa flavonoid dalam kandungan rimpang kunyit akan menempel pada sel imun dan memberikan signyal intraseluler untuk mengaktifkan kerja sel imun agar lebih baik (Agus, K. dan Fauzi, R. K. dalam Dewi, K. dkk., 2014)

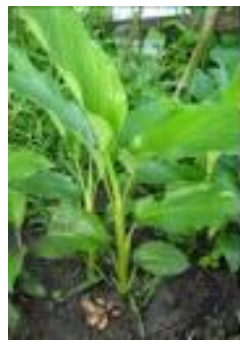

Gambar 1. Pohon dan rimpang kunyit

Berdasarkan hasil penelitian Dewi, K. dkk. (2014), terdapat pengaruh pemberian ekstrak rimpang kunyit terhadap suhu tubuh tikus putih yang diberi vaksin DPT. Dilihat dari nilai deskriptif, penurunan terbesar terjadi pada kelompok maserasi dosis 2 yaitu sebesar $2,33^{\circ} \mathrm{C}$ dan tidak terdapat perbedaan nilai rata-rata penurunan suhu tubuh antar kelompok perlakuan (maserasi dosis
1, maserasi dosis 2, maserasi dosis 3 dan dekok).

\section{Pepaya (Carica papaya)}

Pepaya (Carica papaya L.) merupakan salah satu tanaman berkhasiat obat. Salah satu bagian dari tanaman pepaya yang berkhasiat obat ialah daunnya. Daun pepaya sering dijadikan bahan olahan makanan sehari-hari walaupun rasanya pahit. Masyarakat biasa menggunakan tanah lempung 


\section{Journal of Pharmaceutical Science and Medical Research \\ ISSN 2614-4840 (print) 2614-6118 (online)}

Vol. 1 No. 1 Tahun 2018

ataupun daun jambu biji untuk mengurangi rasa pahit daun pepaya. Khasiat daun pepaya diyakini masyarakat bisa mengatasi demam, keputihan, jerawat, menambah nafsu makan,

sakit gigi. Daun pepaya mengandung senyawa alkaloid, enzim papain, flavonoid, glikosid, karposid, sakarosa, dekstrosa, levulosa, benzilgluko-sinolat dan tannin. menambah air susu ibu, dan mengobati

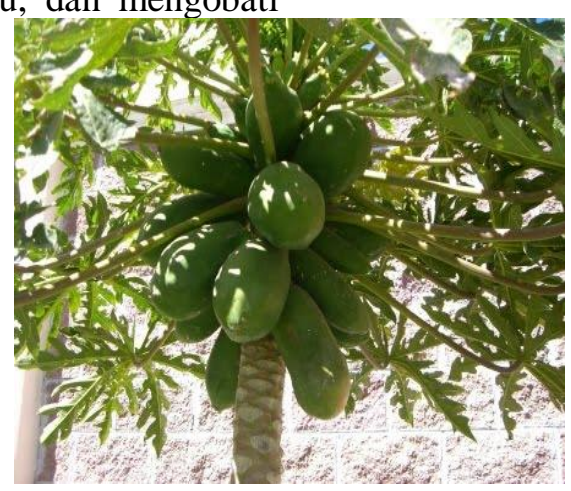

Gambar 2. Pohon pepaya

Berdasarkan hasil penelitian Yapian,S.A.dkk.(2012), hasil uji efek antipiretik ekstrak daun pepaya pada tikus Wistar yang diamati selama 120 menit, dapat disimpulkan bahwa ekstrak daun pepaya dengan dosis $200 \mathrm{mg} / \mathrm{kg}$ BB dapat memberikan efek antipiretik pada tikus Wistar, namun efek antipiretiknya lebih rendah dibandingkan dengan parasetamol.

\section{Dadap serep (Erythrina lithosperma Miq)}

Tanaman Dadap serep (Erythrina lithosperma Miq) termasuk dalam famili papilonaceae merupakan tanaman yang memiliki banyak sekali khasiat sebagai obat tradisional, namun belum banyak masyarakat mengetahuinya. Daun tanaman dadap serep mempunyai khasiat sebagai obat demam bagi wanita (demam nifas), pelancar ASI, perdarahan bagian dalam, sakit perut, mencegah keguguran, sedangkan kulit batangnya dapat digunakan sebagai pengencer dahak (Revisika, 2011).

Uji fitokimia dari berbagai bagian pada tanaman dadap serep dilaporkan memiliki kandungan saponin, flavonoid, polifenol, tannin, dan alkaloid, kandungan zat-zat tersebut inilah yang membuat tanaman dadap serep memiliki fungsi sebagai antimikroba, antiinflamasi, antipiretik, dan antimalaria (Desianti, 2007).

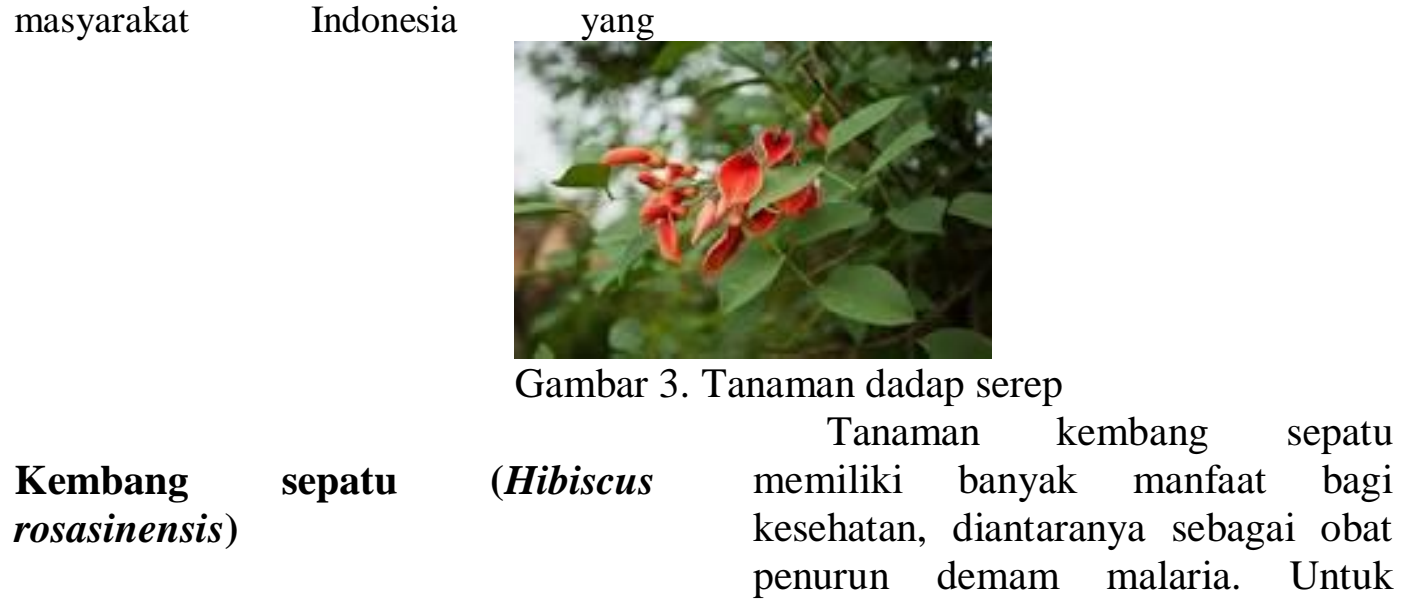




\section{Journal of Pharmaceutical Science and Medical Research ISSN 2614-4840 (print) 2614-6118 (online)}

Vol. 1 No. 1 Tahun 2018

menurunkan demam malaria caranya adalah dengan cara merebus 50 gram daun kembang sepatu dengan $1 / 2$ liter air bersama dengan $1 / 2$ lembar daun pepaya dan ditambahkan 10 gram garam inggris. Campuran tersebut direbus hingga mendidih, kemudian disaring dan diminum airnya selagi masih hangat (Hilwannisa, H.U., 2016).

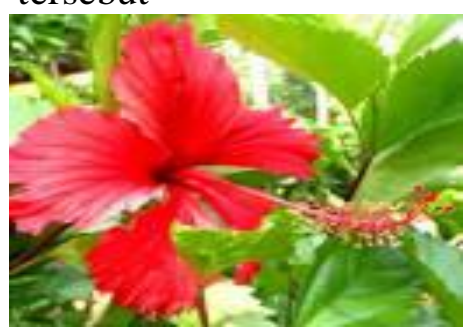

Gambar 4. Kembang sepatu

\section{Rambutan (Nephelium lappaceum )}

Kulit buah rambutan (Nephelium lappaceum L) secara empiris telah dimanfaatkan oleh masyarakat di berbagai daerah di Indonesia sebagai obat penurun demam atau antipiretik (Dalimartha, 2008). Namun kajian ilmiah tentang efek antipiretik dari kulit buah rambutan ini belum banyak dipublikasikan. Hasil penelitian Tjandra, O., (2011) menunjukkan bahwa kulit buah rambutan rapiah mengandungan senyawa steroid, terpenoid, fenolik, dan flavonoid dengan kandungan senyawa fenolik yang dominan dan menunjukkan aktivitas antioksidan yang lebih tinggi dibandingkan dengan asam askorbat.
Kandungan fenolik yang tinggi pada kulit buah rambutan rapiah berpotensi sebagai obat penurun panas karena kemiripan stukturnya dengan senyawa penurun panas sintetik parasetamol yang mengandung gugus fenolik. Hasil penelitian Swantara, I.M.D. dkk. (2017) menunjukkan bahwa ekstrak etanol kulit buah rambutan mempunyai aktivitas antipiretik terhadap tikus jantan galur wistar terinduksi ragi pada semua dosis yang diujikan yaitu $5 \mathrm{mg} / 100 \mathrm{~g} \mathrm{BB} ; 10$ $\mathrm{mg} / 100 \mathrm{~g} \mathrm{BB}$; dan 20mg/100 g BB. Kandungan fenol total dalam ekstrak etanol kulit buah rambutan sebesar $39,7861 \mathrm{~g}$ GAE/ $100 \mathrm{~g}$ atau $39,78 \%$.

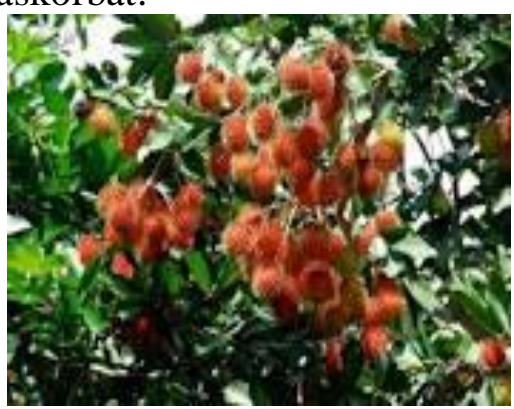

Gambar 5. Pohon rambutan

\section{Pisang (Musa paradisiaca)}

Pisang (Musa paradisiaca) merupakan tanaman berkhasiat obat yang oleh masyarakat dapat digunakan untuk menyembuhkan berbagai macam penyakit seperti pendarahan rahim, ambeien, cacar air, disentri, amandel, kanker perut, sakit kuning (lever), pendarahan usus besar, diare dan luka 


\section{Journal of Pharmaceutical Science and Medical Research \\ ISSN 2614-4840 (print) 2614-6118 (online)}

Vol. 1 No. 1 Tahun 2018

(Dalimartha, 2005). Salah satu jenis pisang yang dikenal baik oleh masyarakat adalah pisang kepok, selain buahnya ada bagian lain dari tanaman pisang yang dimanfaatkan oleh masyarakat yaitu air batang pisang karena banyak mengandung senyawa metabolit sekunder.

Metabolit sekunder merupakan senyawa kimia yang terbentuk dalam tanaman. Senyawa-senyawa yang tergolong dalam kelompok metabolit sekunder antara lain alkaloid, flavonoid, tanin, saponin dan minyak atsiri (Djauharia,E. dan Hermani, 2004). Secara empiris air batang pisang kepok banyak digunakan sebagai pengobatan untuk menurunkan panas (demam).

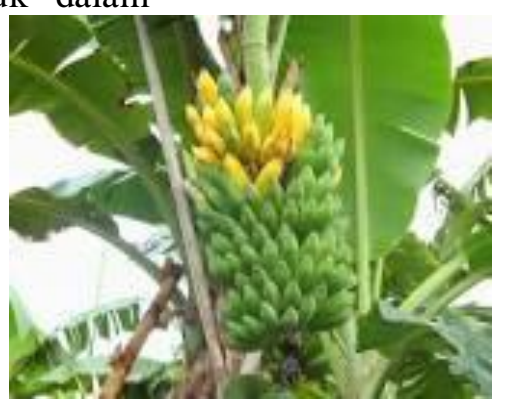

Gambar 6. Pohon pisang

Hasil penelitian Maya, S.W. dkk. (2015) menunjukkan bahwa air batang pisang kepok: mengandung senyawa fitokimia tanin, alkaloid dan saponin serta memiliki efek antipiretik dimana penurunan suhu dari jam 1-4 pada dosis $0,37 \mathrm{~mL} / 200 \mathrm{~g}$ BB yaitu dari 37,1-35,0, pada dosis $0,75 \mathrm{~mL} / 200 \mathrm{~g}$ BB penurunan suhu dari 36,5-34,8 sedangkan pada dosis $1,5 \mathrm{~mL} / 200 \mathrm{~g}$ BB mengalami penurunan suhu dari 35,0-34,1

\section{Sirsak (Annona muricata)}

Menurut Viani dan Hijratul (2016), sirsak (Annona muricata L.) merupakan tanaman tropis yang buahnya memiliki aroma dan rasa yang khas. Masyarakat mengenal sirsak sebagai tanaman buah. Seiring dengan banyaknya penelitian tentang tanaman sirsak maka tanaman ini juga populer sebagai tanaman obat terutama daunnya yang memiliki banyak khasiat untuk beberapa macam penyakit, diantaranya demam, tekanan darah tinggi, tumor, dan sebagai pereda rasa nyeri. Adapun kandungan kimia tanaman sirsak yang berkhasiat sebagai antipiretik adalah flavonoid. Flavonoid menghambat enzim utama dalam biosintesis prostaglandin yaitu siklooksigenase.

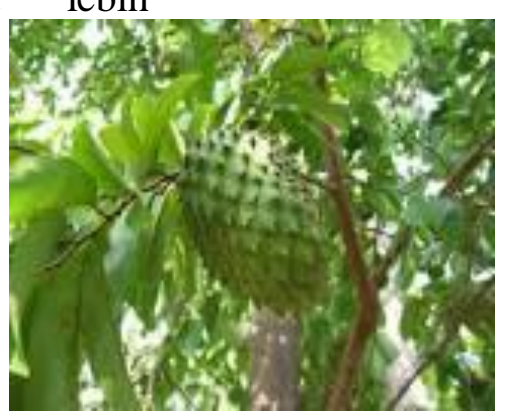

Gambar 7. Pohon dan buah sirsak 


\section{Journal of Pharmaceutical Science and Medical Research ISSN 2614-4840 (print) 2614-6118 (online)}

Vol. 1 No. 1 Tahun 2018

Berdasarkan hasil penelitian terhadap sampel ekstrak daun sirsak (Annona muricata L.) maka dapat disimpulkan bahwa ekstrak daun sirsak (Annona muricata L.) memiliki efek antipiretik terhadap mencit (Mus musculus). Efek antipiretik ekstrak daun sirsak (Annona muricata L.) mempunyai perbedaan efektifitas yaitu pada konsentrasi $60 \%$ dibandingkan konsentrasi $20 \%$ dan 40\% (Viani dan Hijratul, 2016).

\section{Bengkuang (Pachirrhyzus erosus)}

Bengkuang adalah tanaman tradisional yang juga sering digunakan oleh masyarakat untuk menurunkan demam. Hasil penelitian yang dilakukan oleh Lukitaningsih dan Holzgrabe (2014) menunjukkan bahwa bengkuang mengandung senyawa golongan isoflavon, saponin dan flavonoid. Hal ini sesuai dengan hasil penelitian Wiryawan, I.G.A. (2014) yang menunjukan bahwa senyawa flavonoid dalam ekstrak bawang merah (Allium ascalonicum L.) juga dapat menyebabkan penurunan suhu tubuh pada tikus putih yang mengalami demam. Senyawa flavonoid memiliki efek antipiretik dengan cara menghambat kerja enzim COX-3 di hipotalamus sehingga menurunkan set point thermic hipotalamus yang menyebabkan penurunan suhu tubuh (Lukitaningsih,E.,Holzgrabe,U.,2014)

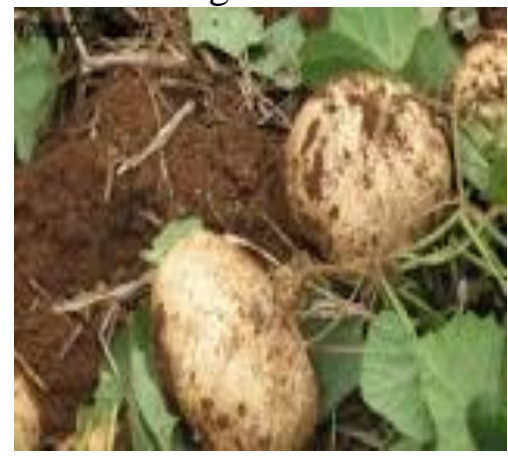

Gambar 8. Tanaman bengkuang

$\begin{array}{ccr}\text { Berdasarkan } & \text { hasil penelitian } \\ \text { Zulfa, N.R.A., } & \text { dkk. } & (2017)\end{array}$ menunjukkan bahwa ekstrak air umbi bengkuang memiliki efek antipiretik pada mencit model hiperpireksia. Dosis 145,6 mg / 20 g BB / kali memberikan efek antipiretik yang paling efektif dengan mula kerja 30 menit dan durasi kerja 90 menit.

\section{KESIMPULAN}

Tanaman yang berkhasiat sebagai antipiretik mengandung metabolit sekunder fenolik yang merupakan golongan senyawa flavonoid.
SARAN

Perlu dilakukan penelitian lebih
lanjut keanekaragaman tanaman obat di pekarangan yang berpotensi sebagai antidepresan sehingga masyarakat menjadi lebih relaxs dan tidak mudah stress.

\section{UCAPAN TERIMA KASIH}

Terima kasih penulis sampaikan kepada: Lembaga Penelitian dan Pengabdian Kepada Masyarakat UPN "Veteran" Yogyakarta yang telah 


\section{Journal of Pharmaceutical Science and Medical Research \\ ISSN 2614-4840 (print) 2614-6118 (online)}

Vol. 1 No. 1 Tahun 2018

mendanai penelitian ini, Dr. Ir. Dwi Fitri Yudiantoro, M.T., Dr. Ir. M. Nurcholis, M.Agr., Dr. Eng. Mirzam Abdurrachman, S.T., Ir. Dewi Sri Sayudi, seluruh masyarakat Dusun Mesu dan Desa Boto, dan pihak-pihak yang tidak dapat penulis sebutkan satu persatu yang telah banyak memberi bantuan dalam pelaksanaan penelitian.

\section{DAFTAR PUSTAKA}

Andriana, D. 2007. Uji Efek Analgesik Perasan Daun Biduri (Calotropis gigantea) Pada Mencit Dengan Metode Geliat (Writhing refleks). Skripsi. Fakultas Kedokteran Gigi Universitas Jember

Dalimartha, S. 2005. Atlas Tumbuhan Obat Indonesia Jilid 1. Jakarta Trubus Agriwidya.

Dalimartha, S., 2008, Atlas Tumbuhan Obat Indonesia, Jilid 5. Jakarta Pustaka Bunda.

Desianti D. 2007. Efek Antipiretik Ekstrak Etanol Daun Dadap Serep terhadap Mencit Jantan Galur $D D Y$. Skripsi. Bandung: Universitas Kristen Maranatha.

Dewi,K., Kadeh, N., Jawi., M., Andriana, D. 2014. Pengaruh Ekstrak Rimpang Kunyit (Curcuma domestica Val) Metode Maserasi dan Dekok Terhadap Penurunan Suhu Tubuh Tikus Putih (Rattus novergicus) Yang Diberi Vaksin DPT.Artikel

Djauharia, E.,Hernani. 2004. Gulma Berkhasiat Obat. Cetakan I.Jakarta Penebar Swadaya.

Hilwannisa, H.U. 2016. Kembang Sepatu (Hibiscus rosasinensis). Islamic
Boarding School Mutiara Qur'an.

Husori, D.I. 2016. Antipiretika Dan Analgetika. Departemen Farmakologi Farmasi. Fakultas Farmasi USU.

Jethani B, Sharma RK, Raipuria M, Jain H. 2011. Antipyretic activity of aqueous and alcoholic extracts of noni on yeast induced pyrexia in rats. Int J Pharm Sci Res. 2(7): 1850-4.

Kohli, K., Ali, J., Ansari, M.J., dan Raheman, Z. 2005. Curcumin: A Natural Anti Inflammatory Agent, Indian J. Pharmacol., 7: 141-147

Lukitaningsih E, Holzgrabe U. 2014. Bioactive Compounds in Bengkoang (Pachyrhizus erosus) As Antioxidant and Tyrosinase Inhibiting Agents. Indones J Pharm. 25(2):68-75.

Leonis, M.A, Alonso, E.M, Belle, S.H, Squires ,R.H. 2013. Chronic acetaminophen exposure inpediatric acute liver failure. Pediatrics. 131(3):740-6.

Maya, S.W.,Citraningtyas, G., Lolo, W.A. 2015. Phytochemical Screening and Antipyretic Effect of Stem juice From Kepok-Banana (Musa paradisiaca $\mathrm{L}$ ) on White Male Rats Stain Wistar (Rattus norvegicus) Induced With DTP-Hb. Pharmacon. Jurnal Ilmiah Farmasi Unsrat. Vol.4 no.1, Februari.ISSN 2302-2493.

Nayudu. S.H., Kavuturu, S., Niazi, M., Daniel, M., Dev ,A., Kumbum ,K. 2013. A rare coexistence:Drug induced hepatitis and meningitis inassociation with ibuprofen. J Clin Med Res.5(3):243-6.

Novri, Y. K., Margaretha, S., Jusna ,A. 2011. Laporan Penelitian Pengembangan Program Studi Dana Pnbp Tahun Anggaran 2011. Kajian 


\section{Journal of Pharmaceutical Science and Medical Research \\ ISSN 2614-4840 (print) 2614-6118 (online)}

\section{Vol. 1 No. 1 Tahun 2018}

Etnobotani Tanaman Obat Oleh Masyarakat Kabupaten Bonebolango Provinsi Gorontalo. Laporan Penelitian Etnobotani Tanaman Obat/Jurusan Biologi FMIPA UNG

Revisika. 2011. Efektifitas Daun Dadap Serep (Erythirna Subumbrans (Hask.)Merr) Sebagai Penyembuh Luka Pada Tikus Putih (Rattus norvegicus Strain Wistar). Skripsi. Malang: Jurusan Biologi F-MIPA, Universitas Muhammadiyah Malang.

Rifatul, 2009. Efek Samping Obat Herbal terhadap Kesehatan Masyarakat. http://www.smallcrab.com/kesehatan / 687-efeksamping-pengobatan herbal. Tanggal Akses 20 Juni 2010.

Risandi Y, Emriadi, Stiadi Y. Ekstrak Daun Pepaya (Carica papaya) Sebagai Inhibitor Korosi Baja St.37 Dalam Medium Asam Sulfat. 2012 Jurnal Kimia Unand. 1(1):27.

Suproborini, A. 2017. Dampak Penambangan Emas Rakyat Terhadap Kandungan Hg Tanah, Air, Tanaman, Struktur Dan Komposisi Vegetasi Di Dusun Mesu Desa Boto Kecamatan Jatiroto Kabupaten Wonogiri .Tesis. Universitas Sebelas Maret Surakarta.

Swantara,I.M.D, Rahman,R.F., Puspawati,N.M. 2017. Aktivitas Antipiretik Ekstrak Kulit Buah Rambutan (Nephelium lappaceum L) Secara In Vitro dan kandungan fenolik Totalnya. Jurnal Kimia 11(2), Juli;107-112.

Tjandra, O., Rusliati, R., dan Zulhipri, 2011, Uji Aktifitas Antioksidan dan Profil Fitokimia Kulit Rambutan Rapiah (Nephelium lappaceum), Karya Ilmiah. Solo.UPT Penerbitan
danPercetakan UNS.

Viani dan Hijratul. 2016. Uji Efek Antipiretik Ekstrak Daun Sirsak (Annona muricata L) Secara Oral Terhadap Mencit (Mus musculus). Prosiding Seminar Nasional Tumbuhan Obat Indonesia Ke-50. Samarinda.20-21 April.

Wan J, Gong X, Jiang R, Zhang Z, Zhang L. 2013. Antipyretic and anti-inflammatory effectsof asiaticoside in Lipopolysaccharidetreated rat through up-regulation of hemeoxygenase-1. Phytother Res. 27(8):1136-42.

Wiryawan IGA. 2014. Skripsi. Efek Ekstrak Bawang Merah .

Yahya M. 2012. Pepaya. Dalam: Novieta N,editor. Khasiat Daun Pepaya Untuk Penderita Kanker. Jakarta: Dunia Sehat; h. 49-60.

Yapian,S.A.,Baras,R.,Awaloei,H.,Waisan .J. 2012. Uji Efek Antipiretik Ekstrak Daun Pepaya (Carica papaya L) Pada Tikus Wistar (Rattus norvegicus). Kandidat Skripsi. Manado.Unsrat.

Yusri DJ, Yorva S, Marlia M. 2015. Kelainan hati akibat penggunaan antipiretik. Jurnal Kesehatan Andalas. 4(3):978-87.

Zulfa.,N.R.A., Sastramihardja,H.S., Dewi, M.K. 2017. Uji Efek Antipiretik Ekstrak Air Umbi Bengkuang (Pachirrhyzus erosus) Pada Mencit (Mus musculus) Model Hiperpireksia. Bandung Meeting on Global Medicine \& Health (BaMGMH), Vol. 1 No. 1 Tahun 37 